\title{
Persistent Symptoms After Discharge of COVID-19 patients
}

\author{
Oğuz Evlice (D), Fatih Kuş² (D), Murat Bektaş3 (D) \\ 1 Department of Infectious Diseases and Clinical Microbiology, Kütahya University of Health Sciences School of Medicine, \\ Kütahya, Turkey. \\ 2 Department of Internal Medicine, Patnos State Hospital, Ağrı, Turkey. \\ 3 Department of Rheumatology, Istanbul University School of Medicine, Istanbul, Turkey.
}

\begin{abstract}
Objective: Many observational studies have reported high morbidity and mortality associated with COVID-19 during hospitalisation. This study aimed to examine the longterm symptoms and related factors of patients hospitalised due to COVID-19.

Materials and Methods: Clinical and laboratory characteristics of 266 patients who were followed up in the hospital with the diagnosis of COVID-19 were recorded. The patients were followed for an average of 14 weeks after discharge. The discharged patients were surveyed for their symptoms by calling.

Results: On average, 14 weeks after being discharged, it was found that a least one symptom persisted in $27.4 \%$ ( $\mathrm{n}=73$ ) of 266 patients. The three most common symptoms after discharge were $38.3 \%(n=28)$ cough, headache $(36.9 \%, n=27)$, shortness of breath $(27.3 \%, n=20)$, respectively. In multivariate analysis, it was found that symptoms persist more in patients with high CRP (C-reactive protein) and ferritin during hospitalisation (p: 0.03; p: 0.005, respectively).

Conclusion: After COVID-19, it was observed that complaints continued after discharge in a significant number of patients. During hospitalisation, high ferritin and CRP levels were found to be associated with the persistence of symptoms. It was considered that symptoms associated with COVID-19 persist more in those with a high inflammatory response.
\end{abstract}

Keywords: Covid-19, Inflammatory Response, SARS CoV-2, Post-COVID-19 syndrome, Persistent Symptoms.

\section{INTRODUCTION}

$\mathrm{M}$ ore than a year has passed since the beginning of the COVID-19 pandemic, and we are learning more about the long-term effects of the disease. While many patients recover completely, some continue to experience fatigue, dyspnea, cough, joint pain, and chest pain for weeks or even months (1).The UK National Institute for Health and Care Excellence (NICE) defined that COVID-19 in three categories according to persistence duration of symptoms:
Corresponding Author: Oğuz Evlice

E-mail:

oguzevlice@hotmail.com

Received: April 10, 2021 Accepted: April 28, 2021 Published: April 30, 2021

\section{Suggested citation:}

Evlice O, Kuş F, Bektaş M.Persistent Symptoms After Discharge of COVID-19 patients Infect Dis Clin Microbiol 2021; 1: $22-30$.

DOI: $10.36519 / \mathrm{idcm} .2021 .40$ 
Acute-COVID: Persist for up to 4 weeks,

Ongoing Symptomatic COVID: 4-12 weeks,

Post-COVID: syndrome continues for more than 12 weeks and cannot be explained with an alternative diagnosis (2).

Although information about the long-term effects of COVID-19 is quite limited, it has been reported that some symptoms such as weakness, shortness of breath and body pain persist even after months $(2,3)$. Our study aimed to examine the persistence of symptoms of patients who were followed up in the hospital with a diagnosis of COVID-19 three months after discharge and possible related factors.

\section{MATERIALS AND METHODS}

\section{Study design and participants}

The study included 266 probable and definite cases older than 18 years of age who were hospitalised with the diagnosis of COVID-19 between 01.07.20201.10. 2020. Case definitions were made according to the World Health Organization definitions. A positive SARS-CoV-2 "real-time" reverse transcriptase chain reaction (RT-PCR) test result in the respiratory tract sample of the patient, as a definite case; the presence of appropriate clinical complaints and the detection of findings compatible with viral pneumonia in thorax computed tomography (CT), although two SARS-CoV-2 RT-PCR tests were negative in the patient, were accepted as possible cases (4). Hydroxychloroquine or favipiravir was started in patients who were evaluated together with clinical, laboratory and radiological findings. Dexamethasone $8 \mathrm{mg}$ or equivalent was started in patients with oxygen saturation (spo2) $<90 \%$ at the time of admission or follow-up. Patients who developed secondary bacterial infections were evaluated in daily visits and antibiotherapy was started when necessary.

\section{Data Collection}

Demographic data of the patients, underlying diseases, laboratory and computerised thoracic tomography (CT) findings were obtained retrospectively from the hospital information system. Patients' admission date, discharge, intensive care transfer/death date, contact history, smoking, symptoms during admission, vital signs at the time of admission, as well as laboratory tests and results were recorded. The highest ferritin and CRP (C-reactive protein) levels and the lowest lymphocyte counts were also recorded during hospitalisation. Hydroxychloroquine, favipiravir, steroid and antibiotic treatments for the diagnosis of secondary infection were recorded. A telephone survey was conducted to evaluate the persistent symptoms of the patients (Supplement).

\section{Statistical analysis}

In our study, the 21.0 version of the SPSS (Statistical Package for the Social Sciences) program (IBM, Armonk, NY, USA) was used to analyse the data. Descriptive statistics are as mean \pm standard deviation or median (minimum-maximum) for discrete and continuous numerical variables; categorical variables were expressed as the number of cases and percentage (\%). Cross-table statistics were used to compare categorical variables (Chi-square, Fisher). Normally distributed parametric data were compared with Student t-test and ANOVA, and non-parametric data that did not suitable to normal distribution were compared with Mann Whitney U and Kruskal Wallis tests. Comparisons between multiple groups were made with Post Hoc Tukey analysis. Multivariate logistic regression analysis was used to evaluate the relationship of clinical and labo-

\section{HIGHLIGHTS}

- After COVID-19, it was observed that complaints continued after discharge in a significant number of patients.

- The three most common symptoms after discharge were cough, headache, shortness of breath.

- Higher CRP levels at admission and higher ferritin values in their follow-up suggested that symptoms continued at a higher rate after COVID-19 in those who showed high inflammatory activity.

- During hospitalization, high ferritin and CRP levels were found to be associated with persistence of symptoms. 
Table 1. Clinical characteristics of the patients with COVID-19.

\begin{tabular}{|c|c|c|c|}
\hline & $\begin{array}{l}\text { Clinical } \\
\text { Variables }\end{array}$ & $\mathrm{n}$ & $\%$ \\
\hline \multirow{2}{*}{ Gender } & Male & 129 & 48.5 \\
\hline & Female & 137 & 51.5 \\
\hline \multirow{2}{*}{ Age } & $<65$ year & 176 & 66.2 \\
\hline & $>65$ year & 90 & 33.8 \\
\hline \multirow{2}{*}{$\mathrm{PCR}^{1}$} & Negative & 73 & 27.4 \\
\hline & Positive & 193 & 72.6 \\
\hline \multirow{2}{*}{$\mathrm{ICU}^{2}$} & No & 255 & 95.9 \\
\hline & Yes & 11 & 4.1 \\
\hline \multirow{2}{*}{ Tobacco usage } & Absent & 236 & 88.7 \\
\hline & Present & 30 & 11.3 \\
\hline \multirow{2}{*}{$\mathrm{HT}^{3}$} & Absent & 156 & 58.6 \\
\hline & Present & 110 & 41.4 \\
\hline \multirow{2}{*}{$\mathrm{DM}^{4}$} & Absent & 193 & 72.2 \\
\hline & Present & 73 & 27.4 \\
\hline \multirow{2}{*}{ COPD/Asthma ${ }^{5}$} & Absent & 217 & 81.6 \\
\hline & Present & 48 & 18.0 \\
\hline \multirow{2}{*}{ Coronary artery disease } & Absent & 233 & 87.6 \\
\hline & Present & 33 & 12.4 \\
\hline \multirow{2}{*}{ Congestive heart failure } & Absent & 255 & 95.9 \\
\hline & Present & 11 & 4.1 \\
\hline \multirow{2}{*}{ Malignancy } & Absent & 264 & 99.2 \\
\hline & Present & 2 & 0.8 \\
\hline \multirow{2}{*}{ Acute renal failure* } & Absent & 263 & 98.9 \\
\hline & Present & 3 & 1.1 \\
\hline \multirow{2}{*}{ Any Comorbidity } & Absent & 112 & 42.1 \\
\hline & Present & 154 & 57.9 \\
\hline
\end{tabular}

1. PCR: Polymerase Chain Reaction 2. ICU: intensive Care Unit 3. HT: Hypertension 4. DM: Diabetes mellitus 5. COPD: Chronic Obstructive Pulmonary Disease *during the hospitalisation ratory parameters with persistent symptoms. The statistical significance was set as $p<0.05$.

\section{RESULTS}

Totally 266 patients, 137 women (51.5\%), were included in the study who were called by phone after an average of $99.80 \pm 26.16$ days after discharge. While $9.8 \%$ of the patients were defined as Ongoing-Symptomatic COVID-19, 90.2\% were defined as Post-COVID-19 syndrome. The mean age of the patients was $56.96 \pm 16.62$ (range $=14-92)$, while $33.8 \%(\mathrm{n}=90)$ were 65 years and older. There was at least one comorbidity in 57.9\% ( $\mathrm{n}=157 / 266)$ of the patients. Among the accompanying comorbidities, hypertension (HT) was the most common $(n=110)$ with a rate of $41.4 \%$; followed by diabetes ( $n=73$ ) with $27.4 \%$ and COPD (Chronic Obstructive Pulmonary Disease) / Asthma with 18.0\% ( $\mathrm{n}=48)$. The need for intensive care admission developed in $4.1 \%$ of the patients ( $\mathrm{n}$ $=11)$. In the treatment of the cases, 50.4\% ( $n=134)$ hydroxychloroquine and 65.8\% $(n=175)$ favipiravir were used (Table 1). The symptoms of the patients during hospitalisation are summarized in Table 2.

While at least one symptom was observed in 19.9\% of the patients $(n=53)$ after discharge, it was observed that $\geq 3$ symptoms persisted in $7.5 \%(n=20)$. While the most common ongoing symptom was cough (38.3\%, $\mathrm{n}=28)$; headache $(36.9 \%, \mathrm{n}=27)$, dyspnea (27.3\%, $\mathrm{n}=20)$, anorexia (23.2\%, $\mathrm{n}=17)$, weakness (17.8\%, $\mathrm{n}=13$ ), myalgia $(16.4 \%, \mathrm{n}=12)$, followed respectively (Table 2).

Persistent symptoms were observed with a rate of $57.9 \%$ in cases with comorbidity; the most common symptom was reported in patients were hypertension $(\mathrm{HT})$ with a rate of $41.1 \%$. This was followed by patients who previously diagnosed with DM (Diabetes mellitus) at $26.4 \%$ and COPD/Asthma at $15.3 \%$, respectively. No significant relationship was found between the presence of persistent symptoms and comorbidities, CT involvement severity, advanced age, gender, smoking, PCR positivity, ICU admission need, and treatments (Table 3).

We present clinical parameters and laboratory findings of patients at the time of admission to the hospital in Table 4. 
Table 2. Prevalence of symptoms during the infection and at follow-up after 12 weeks patients with COVID-19.

\begin{tabular}{|l|c|c|l|c|c|}
\hline During Hospitalisation & $\mathrm{n}$ & $\%$ & Follow-Up & $\mathrm{n}$ & $\%$ \\
\hline Fatigue & 177 & 66.5 & Cough & 28 & 38.3 \\
\hline Cough & 158 & 59.4 & Headache & 27 & 36.9 \\
\hline Shortness of breath & 134 & 50.4 & Shortness of breath & 20 & 27.3 \\
\hline Fever & 94 & 35.3 & Chest pain & 17 & 23.2 \\
\hline Headache & 51 & 19.2 & Fatigue & 13 & 17.8 \\
\hline Nausea & 35 & 13.2 & Anorexia & 17 & 23.2 \\
\hline Diarrhea & 16 & 6.0 & Myalgia & 12 & 16.4 \\
\hline
\end{tabular}

In the univariate analysis, the highest ferritin values during hospitalisation were found to be significantly higher in patients with persistent symptoms (p: 0.04). However, in patients with persistent symptoms, the mean ferritin values are higher, and the lowest mean lymphocyte values are lower, and the statistics tend to be significant. In the multivariate analysis, a statistically significant relationship was found between the high CRP level detected at the time of admission and the presence of persistent symptoms with the height of ferritin detected in the patient's follow-up ( $\mathrm{p}$-value $=0.03$ and 0.005 , respectively) (Table 5).

\section{DISCUSSION}

It has long been known that some symptoms persist for a long time after viral infections. In a study conducted by Magnus et al. In Norway during the influenza A (H1N1) pandemic in 2009, the incidence rate of Myalgic Encephalomyelitis/Chronic Fatigue Syndrome (ME/CFS) was found to be 2.08 per 100,000 people/months. It was found that this rate was higher in patients younger than 30 years old, and researchers thought that the development of ME/CFS was associated with the immune response to influenza (5). It has been reported that patients with SARS (Severe acute respiratory syndrome) continue to have symptoms such as chronic fatigue, myalgia, dysfunction or depression in the long term. It has been reported that these ongoing symptoms are similar to chronic fatigue syndrome and fibromyalgia (6). In a study in which 1733 patients were evaluated, patients who do not need oxygen, those who need intense oxygen and those who need mechanical ventilation were evaluated separately, and it was determined that $76 \%$ of the patients showed at least one symptom at the end of six months. Fatigue or muscle weakness (63\%), difficulty sleeping (26\%), and hair loss (22\%) come first among these symptoms (7). In another study evaluating persistent symptoms after COVID-19, symptom severity was classified as mild, moderate, or severe. The most common persistent symptoms are reported as myalgia $(60.0 \%)$, arthralgia (57.2\%), restriction of daily activities $(57.0 \%)$, sleeping troubles $(50.9 \%)$, followed by anorexia (42.6\%), chest pain $(32.6 \%)$, gastritis $(32.3 \%) \%$, cough $(29.3 \%)$ and dyspnea (29.1\%) (8). In this study, we observed that the symptoms of COVID-19 continued even after an average of three months after hospitalisation in a significant portion of the patients, coherent with previous studies. The most common persistent symptoms of COVID-19 were cough, headache, shortness of breath and loss of appetite and fatigue. Although the retrospective design, the survey method, being a single centre study, and the low number of patients are important limitations of our study, our findings were consistent with previous studies. 
Table 3. Comparison of persistent symptom frequency in cases according to clinical variables.

\begin{tabular}{|c|c|c|c|}
\hline & \multirow{2}{*}{$\begin{array}{l}\text { Clinical } \\
\text { Variable }\end{array}$} & \multicolumn{2}{|c|}{ Persistent Symptoms } \\
\hline & & $\begin{array}{c}\text { Non-Existent } \\
n(\%)\end{array}$ & $\begin{array}{l}\text { Exists } \\
\mathrm{n}(\%)\end{array}$ \\
\hline \multirow{2}{*}{ Age } & $<65$ year & $126(71.6)$ & $50(28.4)$ \\
\hline & $>65$ year & 67 (74.4) & $23(25.6)$ \\
\hline \multirow{2}{*}{ Gender } & Male & $88(68.2)$ & $41(31.8)$ \\
\hline & Female & $105(76.6)$ & $32(23.4)$ \\
\hline \multirow{2}{*}{ Smoking } & Absent & $170(72)$ & $66(28)$ \\
\hline & Present & $23(76.7)$ & $7(23.3)$ \\
\hline \multirow{2}{*}{ PCR } & Negative & $49(67.1)$ & $24(32.9)$ \\
\hline & Positive & $144(74.6)$ & $49(25.4)$ \\
\hline \multirow{2}{*}{ Comorbidity } & Absent & 79 (70.5) & $33(29.5)$ \\
\hline & Present & $114(74)$ & $40(26)$ \\
\hline \multirow{2}{*}{$\mathrm{HT}^{1}$} & Absent & $113(72.4)$ & $43(27.6)$ \\
\hline & Present & 80 (72.7) & $30(27.3)$ \\
\hline \multirow{2}{*}{$\mathrm{DM}^{2}$} & Absent & $139(72.4)$ & $53(27.6)$ \\
\hline & Present & $54(74)$ & $19(26)$ \\
\hline \multirow{2}{*}{ COPD/Asthma ${ }^{3}$} & Absent & $156(71.9)$ & $61(28.1)$ \\
\hline & Present & $37(77.1)$ & $11(22.9)$ \\
\hline \multirow{2}{*}{$\begin{array}{l}\text { Coronary artery } \\
\text { disease }\end{array}$} & Absent & $171(73.4)$ & $62(26.6)$ \\
\hline & Present & $22(66.7)$ & $11(33.3)$ \\
\hline \multirow{2}{*}{$\begin{array}{l}\text { Congestive } \\
\text { heart failure }\end{array}$} & Absent & $186(72.9)$ & $69(27.1)$ \\
\hline & Present & 7 (72.6) & $4(27.4)$ \\
\hline \multirow{2}{*}{ Malignancy } & Absent & $191(72.3)$ & $73(27.7)$ \\
\hline & Present & $2(100)$ & $0(0.0)$ \\
\hline \multirow{2}{*}{$\begin{array}{l}\text { Acute renal } \\
\text { failure }\end{array}$} & Absent & $191(72.6)$ & $72(27.4)$ \\
\hline & Present & $2(66.7)$ & $1(33.3)$ \\
\hline \multirow{2}{*}{$\mathrm{CT}^{4}$} & Mild & $148(74.4)$ & $51(26.6)$ \\
\hline & Severe & $43(67.2)$ & $21(32)$ \\
\hline \multirow{2}{*}{$\mathrm{ICU}^{5}$} & No & $185(72.5)$ & $70(27.5)$ \\
\hline & Yes & 8 (72.7) & $3(27.3)$ \\
\hline
\end{tabular}

1. HT: Hypertension 2. DM: Diabetes mellitus 3. COPD: Chronic Obstructive Pulmonary Disease 4. CT: Computed Tomography 5. ICU: Intensive Care Unit *Fisher's exact test (2-sided)
In inflammatory diseases, ferritin increase is an important marker in terms of macrophage activation and hyperinflammatory response as well as being an acute phase reactant $(9,10)$. However, the increase in ferritin in influenza has been associated with a poor prognosis (11). In a meta-analysis in which 5350 patients with COVID-19 were included; along with acute phase reactants such as procalcitonin and CRP, increased ferritin has been shown to be associated with poor prognosis (12). In our study, the mean CRP and maximum ferritin levels during hospitalisation were found to be higher in patients with persistent symptoms. This indicates that the symptoms continue at a higher rate in patients with a more inflammatory response. Cytokine storm observed in COVID-19 is an important component of severe symptoms and mortality, similar in SARS, MERS (Middle East respiratory syndrome), and influenza (13). In cases with high CRP and ferritin values, a higher cytokine response may have caused the symptoms to persist longer. The elevation of CRP and ferritin in the disease course may be considered as a predictor of persistent symptom development. There are conflicting results in the literature showing the relationship between the presence of comorbidity and persistent symptoms. Patients diagnosed with COVID-19 with underlying health problems or comorbidities tend to progress rapidly and severely. For example, patients with HT or DM were found to have higher intensive care transfer and mortality rates (14). In a study in which 150 non-critical COVID-19 patients with pneumonia but did not need oxygen support were evaluated, it was found that symptoms persist on the 30th and 60th days in twothirds of the patients, the most common symptoms were anosmia/ageusia 55 (64.0\%), fatigue/ weakness (40\% 52/130), dyspnea 30\% (39/130) respectively. Symptoms were seen more frequently between the ages of 40-60, but as in our study, no relationship was found with comorbidity (15). In another study evaluating persistent symptoms, more persistent symptoms were found in patients with comorbidities (8). In our study, no relationship was found between the presence of comorbidity and persistent symptoms. 
Table 4. Comparison of persistent symptom frequency in cases according to laboratory findings patients with COVID-19.

\begin{tabular}{|c|c|c|c|}
\hline & \multirow{2}{*}{ Admission } & \multicolumn{2}{|c|}{ Persistent symptoms } \\
\hline & & Non-Existent & Exists \\
\hline Body Temperature $\left({ }^{\circ} \mathrm{C}\right)$ & $36.80 \pm 0.70$ & $36.83 \pm 0.69$ & $36.72 \pm 0.63$ \\
\hline Oxygen saturation (SpO2) & $89.30 \pm 5.89$ & $89.53 \pm 5.71$ & $88.68 \pm 6.35$ \\
\hline Systolic BP ${ }^{1}(\mathrm{mmHg})$ & $118.4 \pm 14.41$ & $119.1 \pm 14.63$ & $116.6 \pm 13.76$ \\
\hline Diastolic BP ${ }^{1}(\mathrm{mmHg})$ & $72.19 \pm 10.09$ & $72.78 \pm 10.11$ & $70.69 \pm 9.94$ \\
\hline Hemoglobin (g/L) & $13.69 \pm 1.87$ & $13.72 \pm 1.66$ & $13.62 \pm 2.34$ \\
\hline $\mathrm{WBC}^{2}\left(10^{6} / \mathrm{uL}\right)$ & $7.256 \pm 1.003$ & $7.398 \pm 1.162$ & $6.879 \pm 3.191$ \\
\hline Neutrophile $\left(x 10^{9} / L\right)$ & $4.939 \pm 2.797$ & $4.852 \pm 2.701$ & $5.170 \pm 3.043$ \\
\hline Lymphocyte (x10\%/L) & $1.422 \pm 0.763$ & $1.454 \pm 0.744$ & $1.337 \pm 0.811$ \\
\hline Neutrophil/Lymphocyte Ratio & $4.67 \pm 4.93$ & $4.41 \pm 4.34$ & $5.36 \pm 6.22$ \\
\hline BUN $^{3}$ (mg/dL) & $42.85 \pm 32.86$ & $41.91 \pm 32.55$ & $45.35 \pm 33.75$ \\
\hline Creatinine (mg/dL) & $1.05 \pm 0.68$ & $1.04 \pm 0.65$ & $1.08 \pm 0.77$ \\
\hline Glucose (mg/dL) & $133.4 \pm 61.07$ & $130.6 \pm 56.88$ & $141.0 \pm 70.91$ \\
\hline $\mathrm{AST}^{4}(\mathrm{U} / \mathrm{L})$ & $33.48 \pm 17.87$ & $32.94 \pm 16.57$ & $34.91 \pm 20.97$ \\
\hline $\operatorname{ALT}^{5}(\mathrm{U} / \mathrm{L})$ & $28.27 \pm 18.12$ & $27.52 \pm 17.14$ & $30.24 \pm 20.48$ \\
\hline $\mathrm{GGT}^{6}(\mathrm{IU} / \mathrm{L})$ & $48.32 \pm 56.94$ & $47.16 \pm 53.99$ & $51.34 \pm 64.31$ \\
\hline $\mathrm{LDH}^{7}$ (mg/dL) & $297.0 \pm 126.1$ & $287.7 \pm 113.8$ & $321.3 \pm 152.0$ \\
\hline CRP (mg/dl) & $55.49 \pm 93.11$ & $50.41 \pm 46.85$ & $57.42 \pm 105.56$ \\
\hline Ferritin (ng/mL) & $290.8 \pm 293.4$ & $270.2 \pm 277.4$ & $344.7 \pm 327.7$ \\
\hline D-dimer $(\mu \mathrm{g} / \mathrm{mL})$ & $0.63 \pm 1.20$ & $0.55 \pm 1.04$ & $0.83 \pm 1.51$ \\
\hline Troponin (ng/l) & $7.38 \pm 22.01$ & $5.96 \pm 10.56$ & $11.13 \pm 38.23$ \\
\hline Highest Ferritin & $389.0 \pm 362.2$ & $361.2 \pm 342.5$ & $462.3 \pm 402.9$ \\
\hline Highest CRP8 & $68.15 \pm 50.55$ & $66.72 \pm 50.75$ & $71.93 \pm 50.17$ \\
\hline Lowest Lymphocyte & $1.220 \pm 0.655$ & $1.271 \pm 0.695$ & $1.085 \pm 0.518$ \\
\hline
\end{tabular}

1. BP: Blood pressure 2. WBC: White Blood Cell 3. BUN: Blood Urea Nitrogen

4. AST: Aspartate aminotransferase ALT: Alanine aminotransferase

6. GGT: Gamma-Glutamyl Transpeptidase 7.LDH: Lactate Dehydrogenase

8. CRP (C-Reactive Protein)

${ }^{*} \mathrm{p}<0.05$ statistically significant. ${ }^{*}$ Mann-Whitney $\mathrm{U}=$ Alive-Exitus 
Although it is known that the disease has a severe course in patients with comorbidities and that the presence of comorbidity is associated with a poor prognosis $(14,16)$, this patient group may not have persistent symptoms because of the absence of a strong immune response.

Although COVID-19 disease has a high mortality, there is little data on the long-term course of patients who recover. In our study, we observed that some complaints continued (after 12 weeks) in a significant portion of the patients hospitalised for COVID-19. Higher CRP levels at admission and higher ferritin values in their follow-up suggested that symptoms continued at a higher rate after COVID-19 in those who showed high inflammatory activity. Therefore, it is important to plan long-term follow-up of patients diagnosed with COVID-19 with a multidisciplinary approach.
Table 5. Table 5. Multivariate analysis for the persistence of symptoms patients with COVID-19.

\begin{tabular}{|l|c|c|c|}
\hline Age & Odds ratio & $\begin{array}{c}\text { Confidence } \\
\text { interval }\end{array}$ & P value \\
\hline Smoking & 1.239 & $0.56-1.24$ & 0.563 \\
\hline ICU admission & 2.185 & $0.16-2.18$ & 0.163 \\
\hline Favipiravir Treatment & 0.404 & $0.34-0.40$ & 0.345 \\
\hline Congestive Heart Failure & 3.994 & $0.10-3.994$ & 0.100 \\
\hline Hypertension & 1.034 & $0.92-1.03$ & 0.926 \\
\hline Acute renal failure & 0.317 & $0.20-5.28$ & 0.317 \\
\hline Highest Ferritin Level & 1.002 & $1.001-1.002$ & $0.005^{*}$ \\
\hline CRP & 0.99 & $0.98-0.99$ & $0.029^{\star}$ \\
\hline D-Dimer & 0.093 & $0.09-1.26$ & 0.093 \\
\hline
\end{tabular}

Ethical Approval: Ağn Training and Research Hospital Ethics Committee approved the study with the decision number of 30 (11.12.2020).

Peer-review: Externally peer-reviewed

Author Contributions: Concept - O.E.; Design - O.E., M.B.; Supervision - O.E., F.K., M.B.; Funding - O.E., F.K.; Materials O.E.; Data Collection and/or Processing - O.E.; Analysis and/or
Interpretation - O.E.; Literature Review - O.E., M.B.; Writer - O.E., M.B.; Critical Reviews - O.E., M.B.;

Conflict of Interest: The authors have no conflict of interest to declare.

Financial Disclosure: The authors declared that this study has received no financial support.

\section{REFERENCES}

1 World HealthCenters for Disease Control and Prevention (CDC) Long-Term Effects of COVID-19. 2020 Nov 13 (cited 2021 January 11). Available from: https://www.cdc.gov/coronavirus/2019-ncov/ long-term-effects.html.

2 National Institute for Health and Care Excellence (NICE) COVID-19 rapid guideline: managing the long-term effects of COVID-19. 2020 Dec 18 (cited 2021 January 11). Available from: https://www.nice.org.uk/guidance/NG188.

3 Goërtz YMJ, Van Herck M, Delbressine JM, Vaes AW, Meys R, Machado FVC, et al. Persistent symptoms 3 months after a SARS-CoV-2 infection: the post-COVID-19 syndrome? ERJ Open Res 2020; 6: 00542-2020.

4 World Health Organization. Global surveillance for COVID-19 caused by human infection with COVID-19 virus: interim guidance. 2020 March 20 (cited 2021 January 11). Available from: https://apps.who.int/iris/handle/10665/331506. 2020.
5 Magnus P, Gunnes N, Tveito K, Bakken IJ, Ghaderi S, Stoltenberg C, et al. Chronic fatigue syndrome/myalgic encephalomyelitis (CFS/ $\mathrm{ME}$ ) is associated with pandemic influenza infection, but not with an adjuvanted pandemic influenza vaccine. Vaccine 2015; 33: 6173-7.

6 Moldofsky H, Patcai J. Chronic widespread musculoskeletal pain, fatigue, depression and disordered sleep in chronic post-SARS syndrome; a case-controlled study. BMC Neurol. 2011; 11: 37.

7 Huang C, Huang L, Wang Y, Li X, Ren L, Gu X, et al. 6-month consequences of COVID-19 in patients discharged from hospital: a cohort study. Lancet 2021; 397: 220-32.

8 Galal I, Hussein AARM, Amin MT, Saad MM, Zayan HEE, Abdelsayed MZ, et al. Determinants of persistent post COVID-19 symptoms: value of a novel COVID-19 symptoms score. Medrxiv 2020. 11.11.20230052 
9 Kernan KF, Carcillo JA. Hyperferritinemia and inflammation. Int Immunol 2017; 29: 401-9.

10 Rosário C, Zandman-Goddard G, Meyron-Holtz EG, D'Cruz DP, Shoenfeld Y. The hyperferritinemic syndrome: macrophage activation syndrome, Still's disease, septic shock and catastrophic antiphospholipid syndrome. BMC Med. 2013; 11: 185.

11 Lalueza A, Ayuso B, Arrieta E, Trujillo H, Folgueira D, Cueto C, et al Elevation of serum ferritin levels for predicting a poor outcome in hospitalized patients with influenza infection. Clin Microbiol Infect 2020; 26: 1557.e9-1557.e15

12 Huang I, Pranata R, Lim MA, Oehadian A, Alisjahbana B. C-reactive protein, procalcitonin, D-dimer, and ferritin in severe coronavirus disease-2019: a meta-analysis. Ther Adv Respir Dis 2020; 14:1753466620937175.
13 Sun X, Wang T, Cai D, Hu Z, Chen J, Liao H, et al. Cytokine storm intervention in the early stages of COVID-19 pneumonia. Cytokine Growth Factor Rev 2020; 53: 38-42.

14 Sanyaolu A, Okorie C, Marinkovic A, Patidar R, Younis K, Desai P, et al. Comorbidity and its impact on patients with COVID-19. SN Compr Clin Med 2020: 1-8.

15 Carvalho-Schneider C, Laurent E, Lemaignen A, Beaufils E, Bourbao-Tournois C, Laribi S, et al. Follow-up of adults with noncritical COVID-19 two months after symptom onset. Clin Microbiol Infect 2021; $27: 258-63$.

16 Wang B, Li R, Lu Z, Huang Y. Does comorbidity increase the risk of patients with COVID-19: evidence from meta-analysis. Aging (Albany NY). 2020;12(7):6049-6057. doi:10.18632/aging.103000 


\section{SUPLEMENT: POST COVID SYNDROME QUESTIONNAIRE}

\section{(For patients with ongoing symptoms following Coronavirus)}

- $\quad$ This questionnaire was prepared to evaluate the patients' symptoms of COVID-19 that continued 12 weeks after discharge.

- What was your health like before you had Covid-19?

A. I did not have any restrictions on my life

B. I had some complaints:

$\begin{array}{lrl}\text { Cough } & \text { Yes } \square \text { No } \square \\ \text { Headache } & \text { Yes } \square \text { No } \square \\ \text { Shortness of breath } & \text { Yes } \square \text { No } \square \\ \text { Chest pain } & \text { Yes } \square \text { No } \square \\ \text { Fatigue } & \text { Yes } \square \text { No } \square \\ \text { Anorexia } & \text { Yes } \square \text { No } \square \\ \text { MyalgiaYes } & \text { Yes } \square \text { No } \square\end{array}$

- $\quad$ Please tick the description in each column how the patient currently feels following conversation with Clinician

Yes $\square$ No $\square$

1. Do you still have a cough after being discharged?

Yes $\square$ No $\square$

2. Do you still having headache after being discharged?

Yes $\square$ No $\square$

3. Do you still having shortness of breath after being discharged?

Yes $\square$ No

4. Do you still having chest pain after being discharged?

Yes $\square$ No $\square$

5. Do you still have fatigue after being discharged?

Yes $\square$ No

6. Do you still having anorexia after being discharged?

Yes $\square$ No $\square$

7. Do you still have myalgia after being discharged?

Yes $\square$ No $\square$ 